\title{
ANALISIS EKONOMI TERHADAP STRUKTUR, PERILAKU, DAN KINERJA PASAR PUPUK DI JAWA TIMUR (Kasus di Kabupaten Lumajang dan Kabupaten Ngawi)
}

\author{
M. Umar Burhan \\ Agus Suman \\ M. Pudjiharjo \\ Noer Soetjipto
}

Fakultas Ekonomi \& Bisnis Universitas Brawijaya

\begin{abstract}
The objectives of this research are: (1) to analyze the market structure of subsidized fertilizer in East Java, (2) to analyze the need of subsidized fertilizer which should be allocated to their farms, (3) to observe the deviation, if any, of subsidized fertilizer distribution along the distribution channel.This research found that the market structure has the following characteristics: the access of market information is generally quite even among distributors at the same level but not between different level. From the market conduct point of view, it is found that there are rent seeking behaviors resulting in some deviation in distribution channel as mentioned above. It is the result of market structure being characterized by oligopolistic in nature. Such market structure and conducts result in the level of fertilizer prices far above the highest retail price set by the government, but farmers are forced to buy because they are in emergency need.
\end{abstract}

Keywords : Fertilizer, rent-seeking, oligopoly, scarcity.

\section{A. LATAR BELAKANG}

Peranan sektor pertanian dalam pembangunan ekonomi nasional saat ini masih memiliki peranan yang sangat penting. Selama triwulan II 2008, PDB sektor pertanian meningkat 5,1\% di banding capaian pada triwulan I. PDB sektor pertanian menyumbang $0,7 \%$ terhadap pertumbuhan ekonomi nasional (year to year) yang mencapai $6,4 \%$.

Ketersediaan pupuk yang berkua-litas dan mampu untuk mencukupi kebutuhan untuk produksi petanian sangat dibutuhkan untuk keberlangsungan usahatani. Pupuk merupakan salah satu input produksi yang mampu mengoptimalkan hasil produksi perta-nian, dengan perkiraan pening-katan hasil produksi sebesar 30 sampai $40 \%$.

Untuk mendukung upaya penca-paian ketahanan nasional diperlukan dukungan kebijakan, salah satu dianta-ranya adalah Kebijakan di bidang penyediaan pupuk bersubsidi yang diawali pada tahun 2003 s/d 2005 dan dilanjutkan pada tahun 2006.

Guna mendukung tercapainya peningkatan ketahanan pangan nasional, kebijakan pupuk diarahkan pada (1) Penyediaan Pupuk sesuai azas 6 (enam) tepat yaitu tepat jenis, jumlah, 
tempat, waktu, mutu dan harga melalui subsidi pupuk anorganik (Urea, SP-36, ZA dan NPK); (2) pengembangan penerapan pupuk berimbang spesifik lokasi dengan penggunaan pupuk majemuk; dan (3) Pengembangan penggunaan pupuk organik.

Pada awal tahun 2004 (Januari-April), fenomena kelangkaan pupuk dan lonjakan harga pupuk kembali muncul. Kejadian ini juga berulang pada awal musim tanam 2005 dan 2006 (Arifin, 2006). Fenomena kelangkaan pasokan dan lonjakan harga pupuk, khususnya pupuk urea diatas harga HET ditingkat petani yang berulang-ulang seharusnya tidak akan terjadi mengingat produksi pupuk urea dalam negeri melebihi kebutuhan bahkan Indonesia merupakan ekportir utama pupuk urea, sementara distribusi pupuk dikendalikan oleh pemerintah dengan kebijakan tata niaga yang cukup lengkap (Simatupang, 2004).

Dari paparan di atas diharapkan muncul informasi yang mampu diarahkan sebagai acuan dalam memperbaiki aransemen kelembagaan kebijakan subsidi harga pupuk, khususnya distribusi pupuk bersubsidi. Dari uraian tersebut di atas tujuan penelitian ini adalah: Menganalisis struktur pasar pupuk bersubsidi di Jawa Timur; Menganalisis besarnya kebutuhan pupuk bersubsidi oleh petani dan yang dialokasikan dalam Usahatani; Mengetahui terjadinya penyimpangan distribusi pupuk bersubsidi oleh distributor, penyalur dan pengecer.

\section{B. KAJIAN TEORITIS}

\section{Telaah Penelitian Terdahulu}

Penelitian yang dilakukan oleh Nyak Ilham (2001) tentang Dampak Kebijakan Tataniaga Pupuk Terhadap Peran Koperasi Unit Desa Sebagai Distributor Pupuk Tulisan ini bertujuan untuk mengkaji dampak kebijakan penghapusan subsidi dan penglepasan mekanisme tataniaga pupuk pada mekanisme pasar terhadap sistem distribusi pupuk dan kinerja KUD sebagai distributor pupuk pada Lini-IV. Dalam konteks penelitian tentang pupuk di Indonesia, banyak peneliti yang mencurahkan perhatiannya pada perubahan aspek kesejahteraan produ-sen dan konsumen, seperti yang dikata-kan Holtzman. Berikut ini adalah berapa penelitian tentang perpupukan yang pernah dilakukan di Indonesia, seperti yang dilakukan oleh Pitt (1983), Tabor (1988), Obnen (1989), Mark (1991), Roche (1994), Sawit and Obrien (1995), Henyana et. Al. (1993), Situmorang et. Al (1995), Hutauruk (1996), dan Hadi et. al. (1997)

Penelitian Yusmichad Yusdja, dkk (2005) tentang Kajian Sistem Distribusi Pupuk Dan Usulan Penyempurnaannya Pada Tiga Propinsi di Jawa. Kajian ini fokuskan untuk mengevaluasi penerapan kebijakan sistem distribusi pupuk Urea tahun 2005 dan memberikan rekomendasi alternatif perbaikan kebijakan distribusi pupuk tahun 2006. Kajian ini telah dilakukan di Propinsi Jawa Barat, Jawa Tengah dan Jawa Timur. Kajian ini menggunakan metode pemahaman masalah secara singkat (PMSS). Untuk menjawab tujuan dari kajian ini, seperangkat analisis yang diterapkan, yaitu tabulasi silang/frekuensi dan sistem distribusi pupuk. Untuk mendukung kedua analisis tersebut akan dilengkapi dengan data kualitatif berupa informasi pada masing-masing tataran kajian.

Hasil pengamatan di lapang menunjukkan kinerja distributor dari produsen pupuk cukup baik, karena mereka sebenarnya lebih berpengalaman dalam hal teknis penyaluran maupun administrasi pergudangan. Permasalahan justru muncul pada beberapa distributor swasta yang 
sebenarnya tidak mempunyai kemam-puan secara ekonomi maupun teknis (tidak mempunyai kantor, gudang maupun sarana transportasi), namun karena didukung oleh "kekuatan tertentu" mendapat lisensi dari produsen pupuk untuk menjadi distributor.

Valeriana Darwis dan A. Rozany Nurmanaf (2003) tentang Kebijakan Distribusi Tingkat Harga dan Penggunaan Pupuk di Tingkat Petani. Bertujuan untuk Mengevaluasi berbagai kebijakan distribusi pupuk, Mengiden-tifikasi hambatan kebijakan distribusi pupuk dan Kaitan kebijakan dengan tingkat harga dan penggunaan pupuk di tingkat petani. Metode yang digunakan adalah survey dengan menggunakan data primer dan sekunder didaerah Jawa Barat dan Sulawesi Selatan. Analisis yang digunakan adalah analisis secara deskriptif terhadap berbagai macam kebijakan distribusi pupuk dan analisis tabulasi terhadap data primer dari petani. Kesimpulan; Sistem distribusi pupuk bukan penentu kelangkaan dan fluktuasi harga pupuk, tetapi factor eksternal ikut berperan yaitu aktifitas pelaksanaan ekspor pupuk bersubsidi. Petani tidak merespon secara langsung kebijakan distribusi pupuk, tetapi dengan anjuran penggunaan pupuk dan harga produksi

Dalam penelitian ini, penulis sesungguhnya banyak diilhami dan meminjam kerangka dasar teoritik dari penelitian Wittenberg (1989), Wanzala (2003) tersebut. Hanya saja perbedaannya terletak pada pendekatan analisis yang akan digunakan. Dalam Penelitian Wittenberg, (1989), maupun Wanzala, (2003) menggunakan pendekatan sub-sektor dan organisasi industri (SCP approach). Pendekatan SCP yang digunakan kedua peneliti tersebut masih besifat statis, dimana sifat hubugan antara struktur pasar, perilaku pasar dan kinerja pasar sifatnya searah dan statik. Berbeda dengan kedua peneliti tersebut penelitian ini akan menggunakan pendekatan SCP yang dinamik yang digabungkan dengan pendekatan ekonomi kelembagaan. Ada keuntungan menggunakan pendekatan SCP yang dinamik ini, seperti yang dikatakan oleh Scherer (1990). Scherer mengatakan selama ini pendekatan SCP sering menggunakan pendekatan SCP statis, di mana pendekatan ini terlalu bersifat deterministik untuk memahami fungsi ketidaksempurnaan pasar, suatu kondisi yang sering terjadi di Negara sedang berkembang seperti Indonesia. Oleh karena itu model SCP dalam penelitian ini akan menggunakan model SCP yang dinamik seperti yang pernah di pakai oleh Duc (2002).

\section{Pendekatan Komoditas Subsektor Terhadap Analisis Pasar}

Studi terhadap komoditas subsektor menawarkan pendekatan operasional untuk menganalisis performance / kinerja pasar. Pendekatan subsektor dikonseptualkan oleh Shaffer dan kemudian dikembangkan oleh Holtzman (1986). Pendekatan ini tergolong sederhana namun pendekatan yang sangat berguna untuk mengambarkan dan menganalisis paradigma organisasi industri dan paradigma subsektor melalui matriks sistem pangan (food system matrix). Pendekatan subsektor juga menyarankan bahwa pemerintah harus memainkan peranan yang vital dalam mengatur dan memfasilitasi peran pada sistem pembangunan (Holtzman, 1986).

Pendekatan subsektor memfokus-kan pada aspek dinamis dari proses pemasaran yaitu a). mencoba untuk mengidentifikasi peluang dalam meningkatkan efisiensi sistem pemasaran; b). mencoba untuk mendiagnosis halangan untuk meningkatkan efisiensi sistem dan koordinasi; c). mengasumsikan bahwa ada cara-cara alternatif dalam mengatur sistem untuk meningkatkan kepuasan konsumen; d) menentukan peran partisipasi baik untuk sektor publik maupun swasta. 


\section{Operasionalisasi Pendekatan Sub-Sektor}

Pendekatan subsektor didasar-kan pada adaptasi dari teori organisasi industri (Bain, 1959, Scherer, 1980). Teori ini menyatakan bahwa struktur (Structure) S, dari sebuah industri akan berpengaruh kuat terhadap perilaku perusahaan dalam suatu industri (Market Conduct) C, dan selanjutnya perilaku pasar dari perusahaan akan mempengaruhi kinerja pasar (Market Performance) P. Oleh karena itu kerangka pemikiran untuk analisis subsektor memasukan komponen struktur, perilaku pasar dan kinerja pasar.

Definisi dari struktur, perilaku pasar dan kinerja pasar berbeda-beda dari satu peneliti dengan peneliti lain, tergantung dari sektor dan daerah di mana peneliti melakukan penelitian serta persepsi peneliti (Hai, 2002 ). Definisi SCP yang digunakan dalam penelitian ini mengacu pada definisi yang yang pernah digunakan oleh peneliti di sektor pertanian seperti yang pernah dilakukan oleh Van Tilburg (1988) dan Lutz and Van Tilburg (1992), Steffen (1995)

Studi pendekatan sub-sektor diawali dari penjelasan mengenai deskripsi dari sifat komoditi, atau kondisi dasarnya ( seperi distribusi geografik, pola konsumsi, pertumbuhan penduduk, perubahan distribusi penduduk, daya beli konsumen, preferensi konsumen, lingkunan fisik, tipe dan derajad ketidakpastian seperti kebijakan pemerintah, musim dan pola iklim, akses dan atau pentingnya pasar eksternal, hukum dan kebijakan pemerintah, aturan pemerintah, variabel makro ekonomi yang memberikan insentif maupun disentif seperti kebijakan nilai tukar, pajak, tarif dan tingkat suku bunga (Steffen, 1995).

\section{a. Struktur Pasar (Market Structure)}

Mengacu pada karakteristik dari suatu pasar di mana struktur pasar membahas organisasi dari suatu pasar mempengaruhi keadaan persaingan dan penentuan harga di pasar (Bain,1959). Struktur pasar juga berarti karakteristik organisasi yang mana menentukan hubungan yang ditetapkan penjual di pasar dengan supplier actual atau potensial lainnya termasuk perusahaan baru yang mungkin masuk dalam pasar (Duc,2002 ). Indikator utama dari struktur pasar meliputi konsentrasi (jumlah dan ukuran pembeli dan penjual, pengaruh merger dan akuisisi). Karakteristik produk (perishability, persyaratan kualitas, dan diferensiasi produk), degrees of mobility (barrier to entry), karakteristik teknologi (intensitas modal, ukuran efisiensi minumam perusahaan, derajad konglomerasi, kapasitas dan kapasitas penggunaan, spesialisasi dan diverfikasi, dan integrasi vertikal. Organisasi subsektor mengacu pada lokasi, waktu dan kluster fungsi pemasaran, jumlah tahapan, jumlah supply chain yang pararel, sistem informasi (grade, harga, kondisi pasar, ketersedian), tipe transaksi pasar spot, hybrid (kontrak, perjanjian dan kelembagaan pembagian resiko), pemilahan dan sinkronisasi tugas dan skala usaha, karakteristik konsumsi, produksi dan musim (Steffen, 1995).

Dari sudut kelembagaan, struktur pasar juga terdiri dari semua aturan formal dan atau aturan yang mengkoordinasi transaksi dipasar. Setiap pelaku pasar (pedagang) mempunyai aturan-aturan main yang diikuti (Duc,2002)

\section{b. Perilaku Pasar (Market Conduct)}

Berkenaan dengan sekumpulan strategi kompetitif yang dijalankan oleh perusahaan atau sekelompok pedagang guna untuk menjalankan aktivits usahanya. Strategi kompetitif itu meliputi: 
i) Penetapan Harga, ii) Penetapan kebijakan non-harga (promosi, produksi dan strategi distribusi) dan iii) Pencarian strategi yang unggul dan strategi menghalangi pelaku baru.

Menurut teori organisasi industri, karakteristik organisasi dari suatu pasar sebagian besar akan menentukan harga dan strategi yang diadopsi oleh perusahaan oleh karena itu, perusahaan dalam suatu industri akan jatuh pada spektrum kompetisi antara pasar persaingan sempurna dan pasar monopolistic.

\section{c. Kinerja Pasar (Market Performance)}

Pendekatan organisasi industrial maupun pendekatan sub-sektor memfokuskan pada kinerja pasar sebagai akibat dari alternatif bentuk-bentuk pasar. Ada tiga langkah yang digunakan untuk mengevaluasi kinerja pasar: a) Mendefinisikan dimensi performa pasar apa tipe hasil akhir dari industri yang paling penting bagi masyarakat; b) Mendefinisikan norma-norma dari kinerja pasar dan c) mendefinisikan ukuran kinerja pasar apakah matrik atau kriteria akan digunakan untuk mengukur penam-pilan terhadap norma-norma (Bain, 1959)

Pandangan Organisasi industri terhadap kinerja pasar berakar dari model persaingan sempurna yang mana dalam realitas memiliki beberapa keterbatasan dalam analis empiris. Sebagaimana yang dikonseptualkan oleh Bain pada awalnya penemuannya kinerja pasar adalah linear - struktur menentukan perilaku pasar dan selanjutnya perilaku pasar mempengaruhi penanmpilan pasar tetapi tidak ada umpan balik diantara element tersebut meskipun dalam dunia nyata ada feedback diantara aspek-aspek tersebut dalam pemasaran.

\section{KERANGKA PEMIKIRAN DAN HIPOTESIS}

\section{Kerangka Pemikiran}

Langkanya pasokan pupuk dan melonjaknya harga di atas Harga Eceran Tertinggi (HET) disatu sisi, serta lemahnya kemampuan finansial disisi lain, menyebabkan petani tidak mampu membeli pupuk dengan jumlah dan waktu tepat. Hal ini membawa konsekwensi bahwa petani tidak dapat mengalokasikan input pupuk dengan tepat waktu dan tepat dosis, Sebagai akibat lebih lanjutnya adalah tingkat produksi akan menurun.

Adanya tingkat kompetisi yang tinggi dalam distribusi pupuk mampu menghasilkan harga pupuk yang dapat mencerminkan normal price atau harga di mana pelaku pasar mendapatkan keuntungan normal (the rate normal of return). Adapun kerangka pemikiran penelitian ini adalah seperti pada gambar berikut:

Kelangkaan pupuk bersubsidi terjadi diduga adanya perilaku pasar yang bersifat monopoli. Dalam pasar yang monopoli, mempunyai kekuatan untuk membatasi permintaan pupuk yang berakibat terhadap kelangkaan pupuk. Semakin tinggi harga pupuk diluar subsidi tidak berarti petani tidak mampu untuk membeli. Apakah dengan harga pupuk yang tinggi, masih menjamin keuntungan dalam usahatani. Bagi petani sebagai pengguna pupuk, walaupun harga tinggi nampaknya masih antusias untuk membeli dan menggunakan dalam usahataninya. 


\section{Hipotesis} berikut:

Berdasarkan kerangka pemikiran ini, maka dalam penelitian ini disusun hipotesis sebagai

1. Diduga struktur pasar pupuk bersubsidi di Jawa Timur cenderung ke monopoli.

2. Penggunaan pupuk dalam usahatani belum seluruhnya terpenuhi diduga karena kuota distribusi pupuk dari Dinas Pertanian Provinsi Jawa Timur tidak mencukupi dengan kebutuhan riil petani

3. Diduga terjadi penyimpangan distribusi pupuk bersubsidi oleh distributor sehingga terjadi fluktuasi harga tinggi yang melebihi HET.

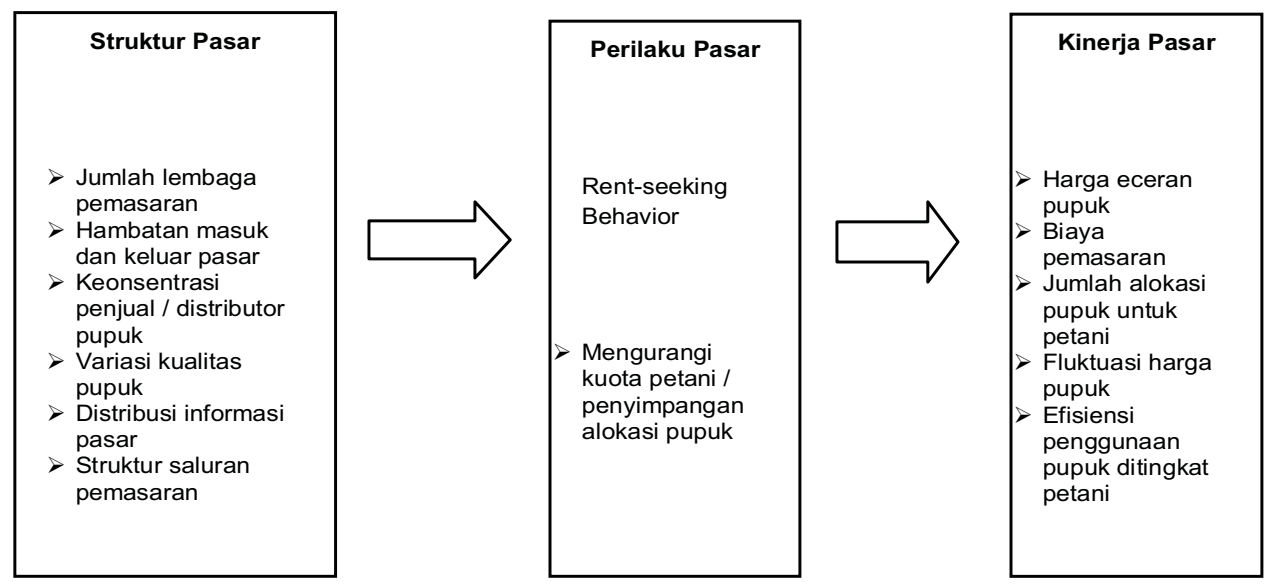

Gambar 1. Kerangka Pemikiran Penelitian

\section{METODE PENELITIAN DAN ANALISIS DATA}

\section{Penentuan Lokasi Penelitian}

Penelitian akan dilakukan di dua Kabupaten di Provinsi Jawa Timur yaitu Kabupaten Ngawi dan Kabupaten Lumajang, Penentuan lokasi dilakukan dengan sengaja (puposive). Dengan pertimbangan bahwa kedua kabupaten tersebut mempunyai persoalan mengenai sub-sektor pupuk yang lebih beragam dibandingkan dengan Kabupaten-kabupaten lain di Provinsi Jawa Timur. Penelitian ini direncanakan akan dilakukan mulai bulan Juni 2007 sampai dengan Agustus 2007.

\section{Metode Penentuan Responden}

Populasi dalam penelitian ini meliputi semua lembaga-lembaga seperti tersebut diatas di mana juga sebagai sumber informasi data, baik data primer maupun sekunder. Dalam penentuan responden yang berhubungan dengan data primer, kuesioner dibatasi pada distributor pupuk di tiap-tiap Kabupaten Lumajang dan Ngawi. Kelompok tani yang diwakili oleh anggota (masyarakat pengguna pupuk) atau petani di tiap-tiap Kabupaten tersebut. Dari hasil survey pendahuluan di dua Kabupaten dapat ditentukan responden untuk Kabupaten Lumajang yaitu 6 distributor dan 35 klompok tani demikian pula untuk Kabupaten Ngawi 


\section{Metode Analisis Data}

\section{Pendekatan Structure, Conduct, dan Performance Markets (SCP)}

Dalam model SCP yang dinamik, model diasumsikan mempunyai hubungan interdepensi atau simultan diantara struktur pasar, perilaku pasar dan kinerja pasar. Struktur pasar dan perilaku pasar akan mempe-ngaruhi kinerja pasar. Begitu pula sebaliknya kinerja pasar akan mempengaruhi struktur dan perilaku pasar dalam jangka panjang. Hal ini jelas berarti bahwa kinerja pada industri atau pasar tertentu dapat dikatakan tergantung pada perilaku dari pembeli dan penjualan dalam kaitan dengan tindakan mereka dalam menetapkan harga, lini produk, investasi fasilitas produksi dan sebagainya. Perilaku pasar tergantung struktur pasar, mencakup gambaran seperti jumlah dan ukuran distribusi dari penjual dan pembeli, tipe saluran pemasaran, derajat differesiansi produk, barrier to entry dst.

\section{Analisis Deskriptif}

Analisis deskriptif dalam penelitian ini dengan bantuan alat statistik deskriptif disertai pembahasan yang meliputi data dalam tabel, grafik, diagram, perhitungan median, mean maupun standard deviasi juga dilakukan pembahasan garis trend dan membandingkan dua atau lebih harga rata-rata. Hasil-hasil analisis baik berupa tabel-tabel dalam bentuk rata-rata atau persen diadakan pembahasan secara deskiptif juga dilakukan dalam mengulas atau menjelaskan terhadap hasil analisis linear berganda.

Analisis fluktuasi harga disajikan dalam tabel silang membutuhkan pembahasan secara deskriptif dan membandingkan serta menjelaskan penyebab terjadinya hasil analisis. Demikian pula pembahasan tentang perkembangan harga yang terjadi selama beberapa tahun dengan disertai faktor-faktor penyebab terjadinya perkembangan harga tersebut.

\section{E. HASIL DAN PEMBAHASAN}

\section{Analisis Struktur, Perilaku, and Kinerja Pasar Analisis Struktur Pasar Pupuk}

Dalam melakukan analisa struktur pasar ini dilakukan dengan analisis deskriptif dengan mengacu pada data-data pasar pupuk yang diperoleh dilapangan. Ada beberapa item dasar yang bisa digunakan untuk menganalisis struktur pasar yang ada yaitu:

a) Lembaga pemasaran yang terlibat pada sistem pemasaran

Secara umum lembaga pemasaran yang terlibat dalam sistem pemasaran pupuk ini merupakan lembaga resmi yang berbadan hukum mulai dari level produsen hingga level konsumen. Keberadaan lembaga pemasaran yang terlibat dalam sistem pemasaran pupuk ini ditentukan berdasarkan mekanisme pemilihan oleh pihak yang berkom-peten. Jumlah lembaga pemasaran pupuk ini cenderung tetap, karena masing-masing sudah ditentukan wilayah kerjanya oleh pihak produsen, yaitu Pabrik Pupuk Petrokimia Gresik. Jenis lembaga pemasaran yang terlibat dalam distribusi atau pemasaran pupuk ini adalah pabrikan, distributor kabupaten, dan pengecer. 


\section{b) Hambatan untuk masuk dan keluar}

Keinginan untuk keluar dan masuk dalam sistem pemasaran pupuk ini cukup sulit, karena sudah adanya pembagian jatah oleh pihak produsen dalam hal ini Petrokimia Gresik. Masingmasing lembaga pemasaran yang ada di dalam rantai sistem pemasaran sudah memiliki daerah operasi masing-masing. Disini ada perbedaan tingkat kesulitan antara keluar dan masuk pasar. Untuk keluar dari sistem pasar akan sangat mudah dilakukan, karena jatah pasar ini akan menjadi rebutan banyak pelaku bisnis (lembaga pemasaran yang lain). Sedangkan tingkat kesulitan yang cukup tinggi adalah untuk masuk dalam sistem pasar yang ada. Akan sangat sulit sekali bagi pelaku baru yang akan masuk ke pasar untuk terlibat dalam sistem pemasaran, apabila tidak memiliki kemampuan modal yang besar dan hubungan khusus dengan pemberi ijin.

Problematika sulitnya masuk dalam sistem pasar komoditas pupuk ini tidak hanya terjadi di level distributor namun juga terjadi di level pengecer. Dari wawancara yang dilakukan di level pengcer menyebutkan bahwa sulitnya masuk kedalam pasar pupuk $18,75 \%$ menyebutkan bahwa ketersediaan SIUP, SITU dan SPJB merupakan penghalang yang cukup signifikan untuk masuk dalam pasar pupuk. Sementara itu, sebanyak 37,5\% menyebutkan bahwa jumlah kios resmi terlalu banyak, sehingga semakin mempersempit peluang-peluang baru bagi pelaku dalam hal ini pengecer baru. Dari temuan dilapang, ada hal yang menguatkan adanya praktik monopoli penyaluran pupuk dari distributor ke pengecer dengan sebanyak 31,25\% menyebutkan bahwa tergantung dari koneksi dengan distributor.

Para pengecer yang mendapat koneksi di tingkat distributor harus menjaga perilakunya terhadap kelompok tani agar hubungan dengan distributor tetap terjalin dengan baik. Faktor koneksi inilah yang merupakan faktor penentu yang sangat sukar untuk dapat diketahui dan diukur. Pemihakan pemerintah terhadap golongan masyarakat tertentu adalah, karena adanya kegagalan pasar (market failure).

Dalam pelaksanaannya, penya-luran pupuk bersubsidi tersebut tidak seindah tujuan awalnya. Bagi petani, cerita tentang pupuk bersubsidi adalah cerita duka yang sepertinya tidak pernah berujung. Gonjang-ganjing kelangkaan pupuk selalu menjadi duka rutin petani setiap memasuki puncak musim tanam.

\section{c) Konsentrasi pembeli dan penjual}

Konsentrasi pembeli dan penjual disini didesain berdasarkan wilayah administratif kabupaten dan kecamatan. Untuk menghindari adanya kecurangan dan pengakumulasian pupuk pada suatu wilayah tertentu, maka perlu didesian tentang penyaluran pupuk secara jelas dan transparan. Maka dari itu peran dari pemerintah selaku penentu dan pengawas kebijakan perlu untuk membuat dan mengawasi kebijakan secara tepat dan konsisten, karena kita ketahui bahwa pupuk merupakan komoditas yang sensitif dan rentan untuk memunculkan konflik apabila ketersediaanya tidak ada di masyarakat, khususnya setelah periode masa tanam atau pada saat pemupukan dilakukan oleh petani.

Dengan adanya zonasi atau pembagian pewilayahan pada masing-masing distributor, hal ini akan sangat sulit untuk mengambil alih pasar dari kompetitor yang lainnya. Namun ditingkat pengecer masih memberi peluang untuk terkonsentrasinya pembeli pada pengecer tertentu, maka hal ini masih memungkinkan untuk terjadinya perebutan konsumen antar pengecer. 
d) Variasi kualitas dan kuantitas produk

Untuk variasi kualitas produk, tidak ada perbedaan kualitas karena adanya standarisasi yang jelas terhadap produk yang bersangkutan. Sementara itu, pada masing-masing level institusi pemasaran tidak bisa atau sulit untuk melakukan pengembangan atau variasi produk. Sementara untuk sisi kualitas, sebenarnya masih memberikan peluang dalam peningkatan jumlah pupuk yang didistribusikan, karena penambahan jatah penyaluran bisa ditingkatkan dengan adanya rencana definitif kebutuhan kelompok (RDKK) oleh kelompok tani.

Permasalahan pupuk bersubsidi yang cukup membuat petani resah pada waktu penggunaan. Pupuk belum tersedia dan walaupun tersedia tentu saja dengan harga yang tinggi.

e) Distribusi informasi pasar

Secara umum distribusi informasi pasar relatif sama diantara para pelaku pasar khususnya dalam satu level yang sama. Namun, ada 8.33 persen dari responden menyebutkan masih adanya ketidakadilan distribusi informasi yang diterima. Hal tersebut mengindikasikan bahwa masih memunculkan peluang adanya asymetric information antar level lembaga pemasaran.

Informasi dewasa ini terutama ditingkat distributor maupun pengecer merupakan hal yang sangat berharga. Informasi disini tentu saja menyangkut ketersediaan pupuk bersubsidi ditingkat distributor dan harga. Dilapang pada tingkatan terendah (kelompok tani), informasi ketersediaan pupuk yang harus didistribusikan pada mereka menurut responden masih terjadi ketidakadilan. Hal ini berarti hanya sebagian kecilpetani saja yang mengerti tentang ketidakadilan informasi dalam hal pendistribusian pupuk bersubsidi. Sebagian besar petani tidak begitu mengerti tentang manfaat dari informasi tentang pupu.Petani hanya tahu kalau pupuk tidak sepenuhnya sesuai dengan yang akan diterima. Hal ini dianggap sudah sering terjadi dan menjadi halyang biasa ditingkat petani. Ke-tidakadilan informasi ini dimana berlaku secara vertikal antara distributor / penyalur terhadap petani. Bagi hubungan secara horizontal, sesama distributor atau sesama pengecer nampaknya berjalan lancar dan terbuka. Sebagian kecil petani dapat merasakan dan mengetahui informasi ini, tetapi merasa kurang adanya keberanian untuk mengungkapkannya.

f) Struktur saluran pemasaran

Stuktur saluran pemasaran pupuk yang ada, secara umum mengacu pada peraturan menteri perdagangan no 3 tahun 2006. Secara struktur, dari data di daerah penelitian secara umum mengacu pada peraturan menteri tersebut. Namun, mendekati level terakhir di tingkatan (end user) terpecah menjadi dua, yaitu ada yang langsung ke tangan petani dan ada yang melalui kelompok tani.

Dalam hal ini, sebenarnya perlu dipertegas peran kelompok tani dalam rantai pemasaran pupuk. Karena, dibeberapa daerah ada perbedaan pemaknaan terhadap kelompok tani. Ada sebagian petani yang menganggap bahwa mereka adalah bagian yang tidak bisa dipisahkan dari kelompok tani. Namun, ada pula yang beranggapan bahwa kelompok tani ini bisa diartikan sebagai individu yang bekerja untuk dirinya sendiri. Mekanisme penyaluran pupuk yang ditetapkan peraturan pemerintah sering tidak applicable. Tidak jarang justru menciptakan kerawanan dalam penyalurannya. Dengan panjangnya rantai penyaluran sering terjadi rent seeking, penyalahgunaan pupuk, kenaikan harga, penimbunan, dan penyelundupan pupuk.

Pada terminologi yang kedua tersebut memunculkan peluang untuk terjadinya asymetric information diantara pengecer atau bahkan distributor dengan petani. Dalam banyak hal 
kelompok tani dapat dilihat sebagai petani yang sedikit lebih diperhatikan dari petani sebagai individu lainnya. Sebagai ketua kelompok tani mereka mengkoordinir para anggota-anggotanya untuk berpeluang mendapatkan pupuk. Dengan situasi dan keadaan kelangkaan pupuk ditingkat petani, maka keadaan ini membuka peluang untuk bertindak sebagai rentseeker dimana ketua kelompok tani mulai mencari keuntungan secara pribadi dan keluar fungsinya sebagai seorang ketua kelompok tani. Dengan terjadinya hal ini keberadaan kelompok tani butuh diperjelas dan diatur secara terintegrasi sebagai bagian dari skema distribusi pupuk yang ditetapkan oleh pemerintah.

\section{g) Proses pembentukan harga}

Pembentukan harga ditentukan oleh pemerintah. Harga yang ditentukan pemerintah adalah sebagai harga dasar ditambah dengan harga yang dibentuk berdasarkan biaya pemasaran. Harga akhir yang diterima oleh petani selaku konsumen adalah harga bentukan yang terdiri dari harga pokok ditambah dengan biaya pemasaran. Harga yang diterima oleh petani tersebut sangat tergantung besar kecilnya biaya pemasaran, sehingga harga yang ada di tingkat petani di masingmasing daerah memiliki nilai besaran yang berbeda-beda.

Permintaan pupuk yang dicerminkan oleh volume penyaluran urea mengalami peningkatan sejak beberapa waktu yang lalu dan mulai mengalami penurunan mulai pada bulan Januari. Pola permintaan pupuk yang bersifat musiman, sedangkan produksi pupuk merata sepanjang tahun, hal ini berakibat pada bulan-bulan tertentu apabila permintaan pupuk meningkat melebihi kapasitas produksi akan menimbulkan kelangkaan yang akan mendorong spekulan distributor atau pengecer menaikkan pupuk diatas harga eceran tertinggi.

Penyebab harga pupuk yang dibayar petani diatas harga eceran tertinggi adalah a) produsen kurang peduli terhadap penyaluran pupuk yang dilakukan oleh distributor dari lini III ke lini IV, sehingga banyak distributor hanya menjual DO (delivery order). Kasus jual beli DO ini akan mengakibatkan kontrol dan pengawasan peredaran pupuk sulit dilakukan dan dapat mengacaukan ketersediaan pupuk disuatu wilayah, seandainya DO tersebut dijual ke pengecer diluar wilayah kerjanya; b) gambaran akibat dari kejadian jual beli DO adalah pengecer resmi yang seharusnya menebus pupuk urea per kg ke distributor franko toko pengecer sebesar Rp.1.020,- akibat ulah distributor menjual DO meningkat menjadi Rp.1.045,- c) selain distributor, pengecerpun berperilaku tidak benar dengan mengambil marjin harga jauh di atas ketentuan (tambahan keuntungan diluar fee); d) kenaikan harga BBM yang menyebabkan kenaikan biaya distribusi dan adanya isu langka pasok yang terjadi pada awal tahun 2006 telah memicu kenaikan harga pupuk lebih tinggi dari tahun 2005.

h) Peraturan dan/atau perundangan yang mengkoordinasikan pertukaran di pasar (aturan main)

Peraturan pemerintah yang ada sebenarnya sudah mengatur sedemikian rupa mengenai mekanisme distribusi pupuk. Perturan yang digunakan sekarang jauh lebih efisien dari sisi distribusi dibandingkan dengan beberapa peraturan terdahulu. Namun yang menjadi kendala dari proses pengimplementasian kebijakan tersebut adalah mengenai besar kecilnya volume pupuk yang didistibusikan. Besar kecilnya permintaan pupuk disuatu daerah bisa dipengaruhi oleh Rencana Definitif Kebutuhan Kelompok (RDKK) yang dibuat oleh ketua kelompok. Pada kondisi ini pemerintah tidak mampu mengontrol besar kecilnya jumlah pupuk yan ada di suatu daerah.

Secara ringkas struktur pasar pupuk bersubsidi di Jawa Timur dilaksanakan oleh lembaga yang resmi berbadan hukum. Distributor ditingkat Kabupaten dan pengecer ditingkat Kecamatan 
ditentukan oleh produsen (pabrik pupuk). Kerja dan wewenang lembaga pemasaran mengarah ke monopoli dengan pembagian kerja tertentu. Dalam teori Duc, 2002 dan Bain, 1959, Dalam struktur pasar harus bukan saja ada hubungan antara penjual dan suplier, tetapi juga mungkin ada perusahaan / lembaga lain yang masuk. Dalam penelitian ini terlihat, bahwa pelaku baru sukar untuk masuk karena diperlukan beberapa persyaratan / ijin untuk masuk kedalam sistem pemasaran. Masuknya lembaga lain, berupa lembaga swasta (Distributor swasta) seperti hasil penelitian Yusmichad, dkk (2007), dapat menyebabkan suatu kelangkaan pupuk pada suatu daerah, hal ini dikarenakan mereka hanya menjual DO saja ke daerah lain.

Struktur pasar pupuk bersubsidi mengacu pada Peraturan Menteri Perdagangan Nomor 3 tahun 2006 tentang Produsen / pabrik, distributor, pengecer dan kelompok tani atau petani. Hanya saja dalam penelitian ini terdapat juga dari pengecer ke petani tanpa melalui ketua kelompok tani. Untuk mengatasi penyimpangan dalam pelaksanaan distribusi pupuk, Ketut K, dkk. (2004) menyarankan agar distribusi dapat berjalan baik perlu adanya komitmen diantara para pelaku pasar dan perlu dikenakan sangsi bagi yang bersalah.

\section{Analisis Perilaku Pasar Pupuk}

Dalam teori ekonomi klasik, seorang pengusaha berusaha memanfaatkan modal yang dimiliki, untuk dapat dikembangkan menjadi modal yang lebih besar. Dengan demikian apapun kegiatan dengan mengorbankan biaya atau jasa, sewajarnya harus menerima upah atau pendapatan. Sehubungan dengan teori rent-seeking, kegiatan lembaga distribusi pupuk pada tingkat kabupaten, merupakan suatu hal yang wajar. Analisis rent-seeking dalam hal pendistribusian pupuk bersubsidi ini, semua perilaku distributor dianggap sebagai pengeluaran sumber daya untuk mengubah kebijakan ekonomi, atau menelikung kebijakan tersebut agar dapat menguntungkan bagi para pencari rente. Seluruh sumber daya ekonomi politik yang dimiliki distributor (pelakunya), seperti halnya, mengadakan lobi dengan lembaga pemasaran (pengecer), adalah untuk mencapai tujuan ekonomi. Dalam hal ini lembaga distributor pupuk bersubsidi, dengan menggunakan hak monopolinya, dapat berbuat kegiatan-kegiatan yang menghasilkan pendapatan.

Praktek seperti ini sudah terjadi cukup lama sejak subsidi harga pupuk diberlakukan yaitu pada tahun 2003 oleh pemerintah. Sejak tahun 2003 kelangkaan pupuk sudah mulai terasa karena ada dua faktor yaitu : a) kebutuhan pupuk lebih banyak dari pada persediaan, sehingga terjadi kekurangan dan b) terjadi disparitas harga yang tinggi antara harga subsidi dan non subsidi. Situasi ini dimanfaatkan oleh beberapa pihak antara lain:

a. Pupuk yang sedianya untuk tanaman pangan saja tidak cukup, dimanfaatkan sektor tanaman perkebunan yang jatahnya lebih sedikit sehingga pupuk subsidi banyak mengalir ke sektor perkebunan

b. Banyak pelaku industri yang bahan bakunya sebagian memakai urea, mereka membeli harga subsidi yang semestinya harus membeli dengan harga non subsidi

c. Perilaku distributor menyalah-gunakan tugas dan wewenang terhadap jumlah pupuk yang harus disalurkan sesuai harga subsidi, berdasarkan pengamatan penulis penyimpangan ratarata $30 \%$ dari total pengawasannya.

Tugas dan perilaku distributor serta pengecer sebagai dasar pelaksanaan rent-seeking, seperti pada tabel berikut: 
Tabel 1. Perilaku Rent-Seeking, Terhadap Distribusi Pupuk di Kabupaten Lumajang dan Ngawi

\begin{tabular}{l|c|c}
\hline \multicolumn{1}{c|}{ Macam Perilaku } & Ju mlah (Orang) & $\mathbf{\%}$ \\
Pengurusan Administrasi Pengecer & 12 & 100,00 \\
\hline Merubah / membatasi permintaan pupuk & 9 & 75,00 \\
Mengadakan lobi, kesepakatan, evaluasi & 10 & 83,33 \\
\hline Fasiltitas Gudang \& Transportasi & 12 & 100,00 \\
\hline
\end{tabular}

Sumber: Pengolahan Data Primer

Dalam Tabel 1 dijelaskan kegiatan / perilaku distributor yang mencerminkan suatu perubahan yang monopoli, dalam penditribusian, pupuk bersubsidi, ditingkat kabupaten. Semua lembaga pengecer, secara administrasi terdaftar di tingkat distributor. Lembaga ini secara total di dua kabupaten Lumajang dan Ngawi dengan responden sejumlah 12 distributor memiliki gudang dan fasilitas transportasi. Lembaga-lembaga ini telah melakukan kegiatan lobi, kesepakatan dan evaluasi di tingkat pengecer yang keseluruhan merupakan jasa yang kelak akan menghasilkan suatu pendapatan. Dalam hal membatasi permintaan pengecer dapat mengakibatkan suatu kebijakan pembatas permintaan yang dapat berakibat awal suatu kelangkaan pupuk. Seluruh perilaku yang telah dilaksanakan merupakan suatu pengorbanan jasa, dengan tujuan akan mendapatkan pendapatan. Pendapatan disini mungkin dapat diperoleh melalui penjualan pupuk (yang tidak didistribusi), dengan harga di luar subsidi, atau pemberian imbalan hasil lobi yang sukar untuk dibuktikan. Secara nyata tidak terbukti akan tetapi, penjualan pupuk dengan harga di luar subsidi, cukup banyak terjadi baik ditingkat pengecer maupun ditingkat masyarakat petani. Kelangkaan pupuk terjadi dikarenakan adanya permainan dari pihak tertentu baik dari produsen sampai pada pengecer, hal ini disebabkan karena Peraturan yang ada memungkinkan pihak tertentu melakukan kegiatan yang dapat merugikan petani sehingga pada saat tertentu pupuk menjadi langka dan harga melebihi HET. Pupuk bersubsidi dan non subsidi hanya berbeda kemasannya (karung) saja sehingga sangat mudah untuk mengganti kemasan saja sehingga akan memperoleh harga yang tinggi.

Secara spesifik kelangkaan yang dapat menyebabkan kenaikan harga pupuk dimana jatah pupuk yang akan didistribusikan oleh distributor ke pengecer hanya dikeluarkan 70\%. Dipihak pengecer merasa kekurangan dan kemudian diadakan negosiasi dan terjadilah kesepakatan harga baru diluar harga subsidi. Kemudian dari pihak pengecer terjadi pula hal yang sama dan harga pupuk pun terjadi peningkatan ditingkat pengguna (petani). Para petani tetap saja membeli, apalagi menjelang waktu pemupukan praktek-praktek seperti ini dapat terjadi karena hal-hal sebagai berikut:

a. Kurang dan lemahnya sistem pengawasan terhadap distribusi pupuk dari tingkat distributor sampai ke tingkat pengecer.

b. Jatah pupuk subsidi sektor pertanian tanaman pangan banyak yang diselewengkan ke sektor perkebunan dan sektor industri yang mestinya tidak berhak mendapatkan harga subsidi.

c. Permainan harga dari tingkat distributor, penyalur sampai pengecer sulit dilacak

d. Sistem penyaluran yang tidak tepat oleh pemerintah, yang lebih mamahami kebutuhan adalah Menteri Pertanian, akan tetapi penyaluran dan distribusi diatur oleh Menteri Perdagangan.

e. Banyaknya petani yang ditangkap oleh penegak hukum akibat membeli pupuk lintas wilayah pemasaran 
f. Disparitas harga subsidi Rp. 1.200,- dan harga non subsidi Rp. 5.500,- mengakibatkan banyaknya spekulan bermain yang mengakibatkan pupuk semakin langka, maka berapapun pupuk disediakan akan tetap terjadi kelangkaan pupuk.

Kelangkaan pupuk yang terjadi, seolah-olah merupakan masalah biasa saja. Untuk mengetahui berbagai macam tanggapan distributor terdapat kelangkaan pupuk bersubsidi dapat dilihat pada tabel 2 .

Tabel 2. Tanggapan Distributor Terhadap Kelangkaan Pupuk Bersubsidi di Tingkat Distributor Kabupaten Lumajang dan Ngawi

\begin{tabular}{l|c|c}
\hline \multicolumn{1}{c|}{ Uraian Tanggapan Distributor } & Jumlah (Orang) & $\mathbf{\%}$ \\
Pengalokasian dari pabrik kurang & 12 & 100,00 \\
\hline Masih terdapat sisa pupuk di gudang & 2 & 16,66 \\
Kelangkaan Pupuk terjadi di tingkat petani & & \\
\hline a. Kebutuhan melebihi yang dialokasi & 8 & 66.66 \\
b. Penggunaan pupuk banyak di luar pe rtanian & 6 & 50,00 \\
\hline c. Petani menggunakan secara berlebihan & 4 & 33.33 \\
\hline
\end{tabular}

Sumber: Pengolahan data primer

Dari tabel 2 di atas terlihat bahwa kelangkaan pupuk terjadi karena pengalokasian dari pabrik kurang dan juga karena masih terdapat sisa pupuk di gudang yang belum terdistribusikan dengan baik. Tanggapan distributor terhadap terjadinya kelangkaan pupuk karena memang petani membutuhkan pupuk lebih besar dari pada yang diperoleh juga karena petani dewasa ini sangat bergairah dalam penggunaan pupuk dalam usahataninya.

Dari uraian tentang perilaku pasar (conduct) di Jawa Timur secara keseluruhan menggambarkan bahwa pendistribusian pupuk oleh lembaga pemasaran (distributor) ke lembaga pengecer dan pengecer ke kelompok tani terjadi perilaku yang sedikit menyimpang baik dari segi jumlah maupun harga pupuk. Dasar terjadinya penyimpangan ini sejalan dengan teori rentseeking Yustika, dkk (2006) yang didukung oleh struktur pasar yang monopoli.

Perilaku distributor yang menyalahgunakan tugas dan wewenang berupa mengurangi jumlah pupuk bersubsidi yang seharusnya dikeluarkan hingga $\pm 30 \%$ dari total yang harus didistribusikan. Dengan mengadakan lobi dengan penyalur untuk memperoleh keuntungan dengan menaikkan harga pupuk bersubsidi menjadi harga umum ke petani. Walupun harga pupuk bersubsidi tinggi ditingkat petani, menurut hasil penelitian Valeriana D dan Rozany (2003) bukan merupakan hambatan pada petani, mereka tetap mematuhi anjuran penggunaan pupuk. Hal ini membuktikan bahwa dalam usahatani, pupuk benar-benar merupakan faktor penentu keberhasilan usahatani.

\section{Analisis Kinerja Pasar Pupuk}

Dalam melakukan analisis mengenai kinerja pasar ini beberapa pendekatan yang bisa dilakukan adalah dengan menganalisis biaya pemasaran, biaya operasional dan biaya transaksi khususnya yang menyangkut dengan permasalahan penawaran. Aktivitas pemasaran yang mampu menunjukkan adanya efektivitas jasa penawaran dan dinamisasi proses pasar, bisa menunjukkan kinerja pasar yang efektif ataupun tidak. 
Biaya pemasaran merupakan bagian yang tidak bisa dipisahkan dalam melihat kinerja pasar. Komponen biaya pemasaran antara lain adalah biaya angkutan. Besarnya biaya angkutan masih merupakan biaya yang normal seiring dengan inflasi dan peningkatan harga BBM. Rata-rata setiap perusahaan atau distributor pupuk menghabiskan biaya sebesar Rp. 32.400.000,- per tahun.

Dari tujuh komponen biaya tersebut, yang terhitung dan terekam oleh para pengusaha adalah biaya pajak, tenaga kerja, listrik dan bahan bakar. Untuk biaya pajak rata-rata sebesar Rp. 600.000,- per tahun. Sedangkan untuk biaya tenaga kerja rata-rata menghabiskan biaya Rp.33.370.000,- per tahun. Untuk biaya listrik dan bahan bakar menghabiskan biaya sebesar Rp. 36.000.000,-. Sementara itu untuk biaya-biaya operasional yang lain tidak terekam. Komponen biaya listrik, bahan bakar dan tenaga kerja ini merupakan komponen biaya yang cukup tinggi dan harus dipersiapkan oleh pengusaha dalam 1 tahunnya. Maka apabila para distributor dan juga pengecer tidak memiliki untung yang cukup dan bahkan merugi maka para distributor khusunya akan mempermainkan komoditas pupuk ini. Seperti yang telah kita ketahui, bahwa selisih harga pupuk bersubsidi dan yang tidak, memiliki selisih yang cukup jauh saat ini. Harga pupuk bersubsidi saat ini HET nya hanya pada level Rp. 1.200 / kg, sedangkan harga pupuk non subsidi mencapai Rp. 6.500,- / kg. Selisih harga yang tinggi tersebut memicu para spekulasi pupuk untuk mempermainkan harga pupuk dipasaran.

Selain komponen biaya pemasaran dan biaya operasional tersebut diatas juga terdapat biaya transaksi yang juga harus ditanggung oleh distributor.

Dari Sembilan komponen biaya transaksi yang diduga tersebut, muncul biaya transaksi yang terdeteksi adalah biaya pajak tanah, DLLAJ, iuran kegiatan sosial seperti pada momen 17 agustus. Dari komponen biaya transaksi yang terekam tersebut besarnya antara lain adalah : biaya pajak tanah sebesar Rp. 128.750,- / tahun, biaya timbangan DLLAJ sebesar Rp. 3.600 .000 selama satu tahun, iuran kegiatan sosial seperti pada momen 17 agustus sebesar Rp 100.000,per tahun. Banyak komponen biaya transaksi yang tidak terungkapkan, hal ini menunjukkan bahwa indikasi pasar yang terbentuk adalah pasar yang oligopoly yang cenderung pada monopoli dengan membentuk sebuah kartel makin memperkuat dugaan.

Dengan struktur pasar pupuk yang tidak kompetitif dan mengarah ke monopoli serta terdapat perilaku yang rent-seeking menyebabkan terjadinya penambahan biaya dari distributor ke penyalur dan kemudian dari penyalur ke kelompok tani / petani. Penambahan biaya pemasaran ini dimasukkan kedalam harga pupuk berupa terjadi peningkatan harga pupuk diatas HET. Dengan peningkatan harga pupuk membuat perilaku dalam penjualan atau pendistribusian pupuk yang tidak semestinya (tidak normal). Proses pendistribusian disini melalui perilaku yang sifatnya tertutup disertai dengan mengadakan lobi antara distributor dengan pengecer serta pengecer dengan kelompok tani. Perilaku ini dilaksanakan karena harus menjual pupuk yang sangat dibutuhkan petani diluar atau diatas harga pupuk bersubidi yang seharusnya praktek pendistribusian ini selain terjadi kelangkaan pupuk juga berakibat kepada petani tidak dapat menggunakan tepat pada saat pemupukan.

Kinerja pendistribusian pupuk bersubsidi secara ringkas sangat berhubungan dengan biaya pelaksanaannya. Hal ini sesuai dengan hasil penelitian Nyak Ilham (2002) yang memperjelas bahwa dalam aktifitas perdagangan terdapat adanya tambahan biaya pemasaran termasuk gudang dan transportasi. Dengan demikian sangat wajar bila pendistribusian pupuk dari distributor ke 
lembaga pengecer terjadi kenaikan harga diatas HET. Perkembangan harga pupuk akibat biaya pemasaran dan kelangkaan pupuk, nampaknya berhubungan dengan harga pupuk yang meningkat dari tahun ke tahun. Kelangkaan pupuk dapat juga terjadi menurut penelitian Nyak Ilham (2002) karena lemahnya fungsi distributor, dimana adanya Unafairness diantara beberapa distributor.

\section{Alokasi dan Kebutuhan Pupuk Bersubsidi pada Tingkat Distributor di Kabupaten Lumajang dan Ngawi.}

Usulan kebutuhan pupuk dan alokasi ditingkat distributor untuk pupuk Urea masih belum sesuai dengan alokasi, terdapat kekurangan yaitu 1,095 ton seperti terlihat pada tabel dibawah berikut:

Tabel 3. Alokasi \& Usulan Kebutuhan Pupuk Bersubsidi (Ton) di Kabupaten Lumajang Tahun 2008

\begin{tabular}{c|c|c|c|c|c|c|c|c}
\hline \multirow{2}{*}{ Distributor No. } & \multicolumn{3}{|c|}{ KEBUTUHAN PUPUK } & \multicolumn{3}{c}{ ALOKASI PUPUK } \\
\cline { 2 - 9 } & Urea & SP-36 & NPK & ZA & Urea & SP-36 & NPK & ZA \\
\hline 1. & 8.395 & 587 & 1.400 & 2.620 & 7.300 & 587 & 1.400 & 2.620 \\
\hline 2. & 8.648 & 590 & 1.315 & 2.632 & 7.520 & 590 & 1.315 & 2.632 \\
\hline 3. & 8.774 & 573 & 1.231 & 2.640 & 7.630 & 573 & 1.231 & 2.640 \\
\hline 4. & 8.660 & 565 & 1.319 & 2.595 & 7.531 & 565 & 1.319 & 2.640 \\
\hline 5. & 8.544 & 592 & 1.316 & 2.615 & 7.430 & 592 & 1.316 & 2.595 \\
\hline 6. & 8.648 & 618 & 1.335 & 2.619 & 7.520 & 618 & 1.335 & 2.619 \\
\hline
\end{tabular}

Sumber: Pengolahan Data Primer, 2008

Berdasarkan informasi atau data ditingkat distributor di Kabupaten Lumajang terjadi kekurangan yaitu sebesar 1.123 ton pupuk Urea. Sedangkan untuk pupuk SP-36, NPK dan ZA tidak terjadi permasalahan, hal ini dikarenakan usulan kebutuhan pupuk oleh distributor sama dengan yang dialokasikan. Jumlah pupuk yang diusulkan sebagai kebutuhan berdasarkan ditingkat pengecer untuk pupuk Urea masih belum sesuai dengan pengalokasian (terdapat kekurangan antara 1.096 hingga 1.129 ton), untuk enam distributor. Kekurangan ini disebabkan karena keterbatasan pupuk yang didistribusikan dari pabrik. Dengan adanya kekurangan pupuk urea ini akan memacu pada tingkat harga yang cenderung mulai meningkat. Keadaan kekurangan pengalokasian ini terlihat hampir sama yang terjadi di Kabupaten Ngawi seperti terlihat pada tabel dibawah berikut:

Tabel 4. Alokasi \& Usulan Kebutuhan Pupuk Bersubsidi (Ton) di Kabupaten Ngawi Tahun 2008

\begin{tabular}{cc|cc|cc|c|c|c}
\hline Distributor & \multicolumn{4}{c}{ Kebutuha PUPUK } & \multicolumn{5}{c}{ ALOKA SI P UPUK } \\
No. & Urea & S P-36 & N PK & ZA & Urea & SP -36 & NP K & ZA \\
\hline 1. & 7.680 & 2.015 & 3.300 & 2.990 & 6.400 & 2.015 & 3.300 & 2.990 \\
2. & 6.840 & 2.002 & 2.800 & 2.700 & 5.700 & 2.002 & 2.800 & 2.700 \\
\hline 3. & 7.560 & 1.900 & 3.450 & 3.050 & 6.300 & 1.900 & 3.450 & 3.050 \\
4. & 8.880 & 2.030 & 3.500 & 3.000 & 7.400 & 2.030 & 3.500 & 3.000 \\
\hline 5. & 8.040 & 2.000 & 2.950 & 2.971 & 6.700 & 2.000 & 2.950 & 2.971 \\
\hline 6. & 8.101 & 2.163 & 3.851 & 3.238 & 6.751 & 2.163 & 3.851 & 3.238
\end{tabular}

Sumber: Pengolahan Data Primer, 2008 
Keadaan pengalokasian dan kebutuhan pupuk di Kabupaten Lumajang juga terjadi pada Kabupaten Ngawi seperti terlihat pada tabel diatas. Dari responden enam distributor di Kabupaten Ngawi, seluruhnya terjadi kekurangan yang hampir sama dengan Kabupaten Lumajang yaitu antara $1.140-1.480$ ton. Kekurangan pengalokasian pupuk Urea di dua Kabupaten memperkuat untuk merangsang kenaikan harga pupuk Urea di tingkat pengecer dan lebih besar lagi pada tingkat pengguna / petani.

\section{Alokasi Dan Kebutuhan Pupuk Bersubsidi di Tingkat Petani Pada Kabupaten Lumajang dan Ngawi.}

Kebutuhan pupuk bersubsidi oleh petani sangat tergantung oleh luas lahan yang digarap. Secara rasional penggunaan pupuk berdasarkan rekomendasi, dengan adanya kekurangan pupuk maka para petani terpaksa membeli dengan harga diluar subsidi. Penggunaan pupuk dalam hal ini berada dibawah tingkat rekomendasi yang telah dianjurkan, meningkatnya harga pupuk akibat terjadi kelangkaan pupuk di mana jumlah yang dibutuhkan petani tidak terpenuhi seperti yang terlihat pada tabel 5 .

Tabel 5. Rata-rata Kebutuhan dan alokasi Pupuk Bersubsidi di Kabupaten Lumajang dan Ngawi Tahun 2008

\begin{tabular}{|lc|c|cc}
\hline $\begin{array}{l}\text { Kabupaten/Jenis Pupuk } \\
\text { Lumajang }\end{array}$ & Kebutuhan (Kg) & Alokasi (Kg) & Sisa (+/-) (Kg) & Harga / Kg (Rp) \\
\hline Luas Lahan & 0,564 ha & & & \\
Urea & 164,28 & 101,43 & $-58,57$ & 2.400 \\
\hline SP-36 & 58,28 & 58,28 & & 1.800 \\
NPK & 106,57 & 59,71 & $-48,29$ & 2.250 \\
\hline Ngawi & & & & \\
\hline Luas Lahan & 0,45 ha & & & \\
Urea & 122,85 & 64,57 & $-58,28$ & 2.400 \\
\hline SP-36 & 47,42 & 47,42 & & 2.800 \\
NPK & 86,42 & 50,42 & $-35,14$ & 2.250 \\
\hline
\end{tabular}

Sumber: Pengolahan Data Primer $(\mathrm{n}=70)$

Dari tabel tersebut diatas terlihat bahwa untuk pupuk urea dan NPK antara pengajuan kebutuhan dan yang dialokasikan tidak sesuai. Sedangkan untuk pupuk SP-36 antara kebutuhan dan alokasinya sesuai.

Dari uraian kekurangan atau terjadi kelangkaan pupuk ditingkat Propinsi, distributor, pengecer dan tingkat pengguna atau petani seperti terlihat disebabkan karena beberapa hal sebagai berikut:

a. Jatah yang ditentukan secara nasional dari pabrik pupuk tidak sesuai dengan yang dibutuhkan oleh Provinsi Jawa Timur. Kebutuhan pupuk di Jawa Timur yang terdiri dari 38 Kabupaten /Kota sebanyak 1,3 juta ton sedangkan yang teralokasi hanya 1,05 juta ton yang berarti terjadi kekurangan sebanyak 0,25 juta ton atau 250.000 ton (kekurangan 19\%)

b. Dengan jumlah pupuk yang teralokasi ke Provinsi Jawa Timur terjadi kekurangan sebesar 19\% yang akan didistribusikan ke 38 kabupaten / kota dimana sudah barang tentu ak an terjadi kekurangan lagi sebesar 19\% tersebut dimana dari tabel 16 dan 17 terlihat kekurangan 
pupuk untuk Kabupaten Lumajang dan Ngawi berkisar antara 1.140 - 1.480 ton untuk pupuk urea. Dengan demikian kelangkaan pasti terjadi akibat permainan distributor ke pengecer dimana jika terjadi kekurangan 19\% (sama dengan) tingkat nasional berarti sampai ke pengecer sudah terjadi kekurangan yang lebih besar dari $19 \%$.

c. Ditingkat pengecer yang mendistribusikan pupuk ke petani, tentu saja akan mempermainkan dengan pengurangan jumlah pupuk yang akan didistribusikan. Dengan permainan mengejar (mencari rente) akan terjadi peningkatan harga pupuk yang melebihi HET.

Ada beberapa sebab mengapa pupuk bermasalah. Pertama, adanya disparitas harga antara pupuk bersubsidi dan tidak bersubsidi. Disparitas ini mengakibatkan distorsi alokasi pupuk. Pupuk untuk petani pun akhirnya berkeliaran ke mana-mana, yang penting "menemukan profit maksimumnya". Di sinilah para spekulan (stockies) melakukan anomali dalam pendistribusian pupuk. Kedua, kelangkaan gas. Seperti diketahui, gas adalah input untuk industri pupuk. Bagi petani, cerita tentang pupuk bersubsidi adalah cerita duka yang sepertinya tidak pernah berujung. Gonjang-ganjing kelangkaan pupuk selalu menjadi duka rutin petani setiap memasuki puncak musim tanam. Pupuk bersubsidi menjadi barang yang paling dicari oleh petani. Mereka berebut membeli, bahkan di beberapa daerah terjadi penjarahan.

Kondisi itu terjadi karena sistem distribusi pupuk bersubsidi yang berlaku selama ini kurang berpihak pada petani. Padahal Peraturan Presiden Nomor 77 Tahun 2005 telah menegaskan bahwa pupuk bersubsidi merupakan barang dalam pengawasan. Oleh karena sasaran penerima pupuk sudah jelas, tidak tepat jika barang tersebut dijual secara bebas dan terbuka. Idealnya sarana produksi ini disalurkan kepada petani dengan cara transfer tunai (cash tranfer) seperti penyaluran bantuan langsung tunai (BLT) atau pembagian beras untuk rumah tangga miskin (raskin).

Pengurangan jumlah pupuk atau yang tidak teralokasi ditingkat petani dapat terjadi sebesar rata-rata baik pupuk urea maupun NPK yaitu sebesar 38. Hal ini belum termasuk penggunaan pupuk untuk tanaman non pangan yang berarti semakin besar pula terjadi kekurangan pangan. Terjadinya kelangkaan pupuk baik ditingkat petani maupun di tingkat distributor dan pengecer terjadi secara proporsional dari tingkat nasional (Jawa Timur), distributor dan pengecer hingga ditingkat petani sebagai akibat perilaku pasar yang tidak kompetitif atau monopoli yang disertai dengan perilaku pelaksana pemasaran yang memang sengaja menjual jasanya dan dinilai dengan menentukan harga yang tinggi dibandingkan dengan harga pupuk bersubsidi yang dikenal dengan pelaku atau pemain rent-seeking. Proses yang terjadi di lapangan bahwa pelaku distributor atau pengecer yang memiliki modal besar dan harus memenuhi persyaratan yaitu Gudang, alat angkutan, kantor dan tenaga kerja yang seluruhnya merupakan suatu jasa yang telah dikeluarkan dalam proses tersebut. Hal ini memberikan suatu keberanian dalam meningkatkan harga melalui pengurangan jumlah pupuk yang dijual dengan harga diatas HET sebagai pelaku rent-seeking untuk dapat menanggulangi semua jasa yang telah dikeluarkan.

Persoalan muncul dari penentu kebijakan, dimulai dari tahun 2002, permasalahan muncul dikarenakan 2 departemen, sampai saat ini belum terpecahkan sebagai contoh yang memerlukan pupuk adalah Deptan tetapi yang menentukan Deperindag hal ini akan menyebabkan kinerja pada Deptan tidak dapat maksimal karena harus tergantung oleh Deperindag.

Untuk meminimalkan penyele-wengan perlu dilakukan pembenahan sistem. Peraturan Menteri Perdagangan Nomor 21/M-DAG/PER/6/2008 tentang Pengadaan dan Penyaluran Pupuk 
Bersubsidi untuk Sektor Pertanian, sudah saatnya direvisi. Peraturan ini lebih kental memihak para kapitalis dibandingkan dengan petani. Peraturan itu harus sinergi dengan Peraturan Menteri Pertanian Nomor 42/Permentan/OT.140/09/ 2008 tentang Kebutuhan dan Harga Eceran Tertinggi Pupuk Bersubsidi untuk Sektor Pertanian Tahun 2009. Peraturan yang mulai berlaku 1 Januari 2009 ini pada Pasal 6 menegaskan bahwa penyaluran pupuk bersubsidi dari lini IV ke petani/ kelompok tani harus mengacu Rencana Definitif Kebutuhan Kelompok (RDKK).

Pada tahun 2002 subsidi dicabut oleh pemerintahan Gus Dur petani sudah terbiasa dg pasar bebas dengan harga dari 900 menjadi 1050, sampai akhirnya tahun 2003 subsidi pupuk diberlakukan dengan 1,3 $\mathrm{T}$ yang artinya petani sudah biasa dengan harga bebas tetapi pupuk selalu ada dipasaran dengan diberlakukannya subsidi tetapi pupuk selalu langka di pasaran, baru 4 bulan SK Mentan \& Memperindag diberlakukan keadaan sudah kacau, walaupun 2 bulan kemudian SK diperbaharui tetapi tetap tidak dapat menyelesaikan permasalahan, hal ini akan mengakibatkan naluri seorang pedagang dengan banyaknya spekulan yang bermain dengan menaikkan harga sekehendak hatinya. Begitu pemerintah memberlakukan subsidi persoalan tidak dapat tersele-saikan walaupun peraturan-peraturan sudah dibuat, hal dikarenakan pabrik pupuk kesulitan membeli gas. Walaupun di Indonesia banyak berdiri tambang gas akan tetapi yang menentukan harga masih ditentukan oleh perusahaan asing, hal ini dipicu oleh kepemilikan saham yang hampir $90 \%$ dikuasai oleh pihak asing, sedangkan yang hanya $10 \%$ milik pemerintah. Persoalan baru akan muncul, apakah pemerintah berani merevisi UU Migas, Undang-Undang Migas kita masih membuka ruang untuk diintervensi. Misalnya, pasal 22 UU No. 22/2001. Pada pasal ini disebutkan bahwa pihak perusahaan hanya diberikan kewajiban mensuplai migas paling banyak $25 \%$ untuk kebutuhan dalam negeri. Tampak sekali bunyi pasal ini mengingkari kepentingan nasional bangsa ini, dan lebih tunduk pada kekuatan modal. Apabila pemerintah berani mengubah UU migas maka akan menyelesaikan sebagian masalah yang dihadapi yaitu tersedianya gas yang sangat dibutuhkan sebagai bahan baku utama pembuatan pupuk urea. Kebijakan pemerintah memberi peran lebih besar kepada pihak swasta dalam penyaluran pupuk, memberikan dampak yang merugikan para petani karena kelangkaan pupuk pada level petani, akibatnya produksi gabah petani menurun. sebaik apa pun sistem dan peraturan dibuat, tanpa komitmen moral dan politik yang tinggi dari seluruh pemangku kepentingan untuk melaksanakannya, hasilnya akan sia-sia. Sebaik apa pun sistem dan peraturan dibuat, pasti terdapat celah-celah untuk 'bermain'. Pengawasan yang intensif dan penegakan hukum yang tegas merupakan kata kuncinya

Sistem distribusi pupuk bersubsidi yang berlaku saat ini perlu diubah dari system distribusi yang bersifat pasif dan tidak lengkap ke system distribusi yang bersifat aktif dan lengkap. Hal ini dimaksudkan untuk mengatasi sejumlah kelemahan dari system distribusi yang berlaku saat ini seperti : rawan penyimpangan dan manipulasi perhitungan besaran subsidi di tingkat pengecer / kios, tidak tepat sasaran, tidak mampu mengatasi dualism harga, dan petani cenderung menggunakan pupuk diatas reko-mendasi (over intensification). Pupuk di lapang selalu langka dan selalu jadi bumerang dikarenakan dari jumlah alokasi yang diperuntukkan Provinsi jawa timur sudah terjadi kekurangan 250.000 ton, hal ini akan dimanfaatkan distributor untuk berbuat rent-seeking, perilaku tersebut didukung oleh infrormasi pasar yang akurat tentang permintaan pupuk di daerah tertentu dengan cara mempermainkan baik darivolume maupun harga. 
Dalam hal mendapatkan informasi, para distributor mengeluarkan biaya tambahan yang nantinya akan dimasukkan pada biaya produksi. Dengan kekuatan distributor yang memiliki pasar yang jelas dan didukung juga oleh pengecer maka distributor dengan mudah mempermainkan harga yang akhirnya sampai pada petani dengan margin harga yang cukup tinggi. Dalam hal ini walaupun pemerintah telah melaksanaan pengawasan terhadap sistem distribusi pupuk akan tetapi kejadian penyimpangan ini masih terus berlanjut.

Dari kondisi semacam ini sampai sekarang tidak ada perubahan di lapangan, dalam hal penyaluran barang bersubsidi akan tetapi lembaga penyalurnya murni swasta yang pada akhirnya selalu memikirkan keun-tungan yang sebesar-sebarnya. Kedepan bagaimana pemerintah dapat membawa petani tidak condong untuk menggunakan pupuk kimia, petani diarahkan untuk kembali menggunakan pupuk anorganik, hal ini sudah terbukti pada masa lalu petani sudah mampu menghasilkan padi dengan kualitas yang baik dan unsur hara tetap terjaga sehingga pertanian dapat berkelanjutan dan tidak merusak tanah.

Mekanisme penyaluran pupuk yang ditetapkan peraturan pemerintah sering tidak applicable. Tidak jarang justru menciptakan kerawanan dalam penyalurannya. Dengan panjangnya rantai penyaluran sering terjadi rent seeking, penyalahgunaan pupuk, kenaikan harga, penimbunan, dan penyelundupan pupuk. Untuk menga-tasi hal tersebut diatas, seyogyanya mengoptimalkan kembali peranan KUD-KUD atau pembentukan BUMP yang keseluruhannya baik organisasi pengelola maupun modal lebih besar ditangani oleh petani sendiri, hal ini akan berdampak pada petani yang akan membeli pupuk tidak lagi membeli pada distributor atau swasta. Pada fase ini seleksi alam akan terjadi dan dengan sendirinya atau kedepan lembaga penyalur pupuk akan beralih ke BUMP yang tentu saja akan mensejahterakan para petani.

\section{F. KESIMPULAN DAN REKOMENDASI}

\section{Kesimpulan}

Berdasarkan permasalahan, tujuan dan hipotesis dalam disertasi ini, maka kesimpulan yang dapat ditarik adalah sebagai berikut :

\section{A. Struktur Pasar}

Lembaga pemasaran yang terlibat dalam sistem pemasaran pupuk bersubsidi adalah lembaga resmi berbadan hukum yaitu Pabrik, Distributor tingkat Kabupaten dan Pengecer yang ditentukan oleh produsen / pabrik pupuk. Jumlah lembaga pemasaran cenderung tetap dengan memiliki wilayah kerja tertentu. Produsen / pabrik cenderung memonopoli penyaluran pupuk ke distributor dan penyalur, sangat tergantung pada koneksi dengan distributor. Konsentrasi pembeli dan penjual didesain berdasarkan wilayah administrative Kabupaten dan Kecamatan. Ditingkat pengecer masih memberi peluang membeli pada pengecer tertentu, sehingga masih memungkinkan terjadi perebutan konsumen antar pengecer. Secara umum distribusi informasi pasar relatif sama diantara pelaku pasar (satu level sama) tetapi masih terdapat ketidak adilan distribusi informasi yang diterima berarti ada peluang asymmetric information antar level lembaga pemasaran. 
Struktur saluran pemasaran pupuk bersubsidi mengacu pada Peraturan Menteri Perdagangan No. 3 Tahun 2006 yaitu produsen / pabrik distributor, pengecer dan kelompok tani / petani. Dalam pelaksanaan ditingkat pengecer langsung melalui kelompok tani baru ke petani. Ada juga yang dari pengecer langsung ke petani, bahkan tingkat distributor langsung ke petani. Hal ini berarti terjadi asymmetric information diantara pengecer juga distributor. Harga pupuk ditentukan oleh pemerintah sebagai harga dasar ditambah dengan harga yang dibentuk berdasarkan biaya pemasaran (tingkat petani) yang berbeda-beda untuk masing-masing daerah.

Dari uraian diatas, dapat dikatakan bahwa dalam struktur pasar masih terdapat ketidakadilan distribusi informasi yang diterima antar lembaga pemasaran.

\section{B. Perilaku Pasar}

Dalam pendistribusian pupuk oleh lembaga pemasaran (distributor) ke lembaga pengecer, terjadi perilaku yang sedikit menyimpang baik dari segi jumlah maupun harga. Dasar penyimpangan ini sejalan dengan teori rent-seeking yang didukung dengan perilaku atau sifat monopoli.

Perilaku distributor yang menyalah gunakan tugas dan wewenang, berupa mengurangi pupuk bersubsidi yang seharusnya dikeluarkan hingga $\pm 30 \%$ dari total. Dengan perilaku penyalur untuk memperoleh keuntungan dengan menaikkan harga pupuk bersubsidi. Dengan praktek mengurangi jatah pupuk, mengakibatkan kelangkaan pupuk ditingkat petani dan harga pupuk dapat meningkat antara $100-400 \%$.

Dalam uraian kesimpulan ini dapat dikatakan bahwa terjadi perilaku yang sedikit menyimpang, baik dari segi jumlah maupun harga pupuk sejalan dengan teori rent-seeking yang didukung oleh perilaku monopoli.

\section{Kinerja Pasar}

Kinerja pasar pupuk bersubsidi sangat berhubungan dengan pembiayaan dalam proses pemasaran yang dilaksanakan oleh distributor, terutama biaya pengangkutan. Adanya biaya biaya pemasaran memacu distributor atau pengecer untuk meningkatkan harga dapat berada diatas HET karena tambahan biaya yang diberikan dalam proses pemasaran harus mendapat imbalan berupa keuntungan yang memadai.

Perkembangan harga pupuk dari tahun ke tahun mengalami peningkatan, sejalan dengan kelangkaan pupuk yang terjadi terutama pada saat musim tanam.

Petani sanggup membeli pupuk dengan harga yang tinggi, asalkan tepat pada waktu yang diperlukan.

Dengan demikian dapat dikatakan bahwa terjadi peningkatan harga pupuk bersubsidi diatas HET, namun petani tetap dapat membeli, terutama pada saat benar-benar membutuhkan

\section{Rekomendasi}

Berdasarkan kesimpulan yang telah diuraikan diatas, maka perlu disarankan hal-hal sebagai berikut: 


\section{A. Struktur (Structure) Pasar}

Untuk menghilangkan keadaan pasar yang tidak kompetitif diperlukan adanya keseimbangan antara penjual dan pembeli, dimana dalam hal ini perlu penambahan lembaga pemasaran (distributor, penyalur dan pengecer) dalam menangani pendistribusian pupuk agar tidak terjadi monopoli. Demikian keterbukaan informasi baik ditingkat distributor, penyalur, pengecer maupun kelompok tani terutama tentang volume, harga dan waktu pendistribusian.

\section{B. Perilaku (Conduct) Pasar}

Agar distributor tidak berperilaku (menyalahgunakan wewenang) diluar yang semestinya dilaksanakan, perlu adanya suatu pengawasan baik ditingkat Kabupaten maupun ditingkat pedesaan. Pengawasan ditiap-tiap tingkat lembaga pemasaran dapat menghilangkan / mendeteksi penyimpangan yang berhubungan dengan jatah pupuk baik ditingkat distributor, pengecer maupun ditingkat kelompok tani.

\section{Kinerja (Performance) Pasar}

Dalam menentukan tingkat harga pupuk bersubsidi, sedapat mungkin diperhatikan proses pemasaran yang cukup banyak mengeluarkan biaya. Dengan adanya tambahan insentif bagi para pelaku pemasaran agar harga pupuk benar-benar sesuai dengan ketentuan yang ditetapkan.

\section{DAFTAR PUSTAKA}

Allgood, J.H. and J. Klingu, (1996), An Appraisal o Fertilizer Market in Kenya and Recommendation for Improving Fertilizer Use Practises by Smallhollder Farmers : A Fileld Report : Prepared Under contract by International Fertilizer Development Center And Department of Agricultural Economics, University of Nairoby fo USAID, Nairobi, Kenya

Anandita, Ratya, (2004), Pemasaran Hasil Pertanian, Papyrus

Arwings-Kodeks, (1999), Policy Issues Facing the Maize Sektor in North Rift, Background Document for Maize and Wheat Stakeholder Consultation, Tegemeo Institute of Agricultural Policy and Deelopment, Desember

Bain, Joe S. (1968). Industrial Organization, 2nd Edition, John Wiley, New York.

Bain, Joe S. ,(1954), Economies of Scale, Concentration, and the Condition of Entry in Twenty, The American Economic Review, Vol. 44, No. 1. (Mar., 1954), pp. 15-39.

Barret,C,B, (1996). Market Analysis Methods: Are our enriched Toolkits We-suited to Enlived Markets, American Journal of Agricultural Economics, Vol. 78, pp:825-829

Denbaly, Mark and Harry Vroomen, (1993), Dynamic Fertilizer Nutrient Demands for Corn: A Cointegrated and Error-Correcting System, American Journal of Agricultural Economics, Vol. 75, No. 1. (Feb., 1993), pp. 203-209.

Engle, R.F., and Granger, C.W.J., (1987). Cointegration and Error Correction: Representation, Estimation and Testing. Econometrica 55 (2), 251-276.

Freeman, H. Ade, and Wachira Kaguongo, (2003). Fertilizer Market Liberalization and Private Retail Trade in Kenya, Food Policy 28 : $505-518$ 
French, Ben C., (1974), Subsektor as a Conceptual Framework for Guiding and Conducting Research, American Journal of Agricultural Economics, Vol. 56, No. 5, Proceedings Issue. (Dec., 1974), pp 1014-1022.

Furubotn, Eirik dan Rudolf Richter (2000), Institutions and Economics Theory: The Contribution of The New Institutional Economics, Ann Abror USA The University of Michagan Press

Gibson, M. Troy (2003). Future Employment Promises as Rent-Seeking in Representative Government. International Journal of Social Economies. Vol.30 No.1/2. pp. 73-74.MCB UP Limited.

Harriss, (1979), There is Method in My Madness: Or is it vive versa< Measuring Agricultural Market Performance: Food Research Institute Studies 17: 197-218

Hendayana, R, A. Suryana, \& Erwidodo, (1993), Studi Kebijaksanaan harga dan Subsidi Pupuk di Indonesia. Pusat Penelitian Sosial Ekonomi Pertanian. Departemen Pertanian, Jakarta.

Hadi, P.U., Hendiarto, \& I.W. Sudana, (1997) Analisisi Kemampuan Petani. Laporan Penelitian Pusat Penelitian Sosial Ekonomi Pertanian. Departemen Pertanian, Jakarta.

Hai, Luu Thanh Duc, (2002), The Organization of Liberalized Rice Market in Vietnam, Dissertation for Faculty of Economic at Univeristy of Gottingen

Holtzman, John .S. (1986). Rapid Reoinnanissance Guideline for Agricultural Marketing and Food System Research in Developing Countries, MSU International Development Papers, Working Paper No. 30, East Lansing

Holtzman, John S., (2002), Using Subsektor Analysis to Assess the Impact of Policy Reform on Commodity Subsektors, Report No. 27 USAID,

Hutauruk, J. (1996), Analisis Dampak Kebijakan Harga Dasar Padi dan Subsidi Pupuk terhadap Permintaan dan Penawaran Beras di Indonesia. Program Pascasarjana IPB, Bogor.

Ilham, N. 2001. Dampak Kebijakan Tataniaga Pupuk terhadap Peran Koperasi Unit Desa sebagai Distributor Pupuk. SOCA Vol.1 No.3 : 218-226 (Juli 2001). Fakultas Pertanian Universitas Udayana

Ilham, N. 2002. Pola Pemasaran Dan Ketersediaan Pupuk Pasca Kebijakan Pengendalian Distribusi Pupuk Urea Maret 2001. Pusat Penelitian dan Pengembangan Sosial Ekonomi Pertanian, Badan Penelitian dan Pengembangan Pertanian, Bogor

Jayne, T.S., J. Govereh, M.Wanzala,and M.Demeke, (2003), Fertilizer Market Development:a Comparative Analysis of Ethiopia, Kenya, and Zambia, Food Policy 28 : 293 -316

Johansen, S, (1981), Statistical Analysis of Cointegration Vector,Journal of Economic Dynamic and Control, 12:231-254.

Kariyasa, Ketut dan Yusmichad Yusdja,(2005), Evaluasi Kebijakan Sistem Distribusi Pupuk Urea di Indonesia : Kasus Provinsi Jawa Barat, Analisis Kebijakan Pertanian. Volume 3 No. 3, September $2005: 201-216$

Kariyasa, K, M. Maulana dan Sudi Mardianto. 2004. Usulan Tingkat Subsidi dan Harga Eceran Tertinggi (HET) yang Relevan Serta Perbaikan Pola Pendistribusian Pupuk Di Indonesia. 
Analisis Kebijakan Pertanian Volume 2 Nomor 3, September 2004. Pusat Penelitian dan Pengembangan Sosial Ekonomi Pertanian. Bogor

Kohls, R. L., J. N. Uhl, (2002), Marketing of Agricultural Product, Ninth Edition Prentice-Hall

Kotler, P. (1997). Marketing Management: Analysis, Planning, Implementation, and Control, 9th Edition. Upper Saddle River, NJ: Prentice Hall International.

Krueger, Anne O., (1990). Government Failure in Development the Journal fo Economics Prespectives. Vol. 4. Issues 3, Summer : 9 - 23.

Krueger, (2000). Government Failure in Development. Dalam Jeffrey Frienden, et.al. Modern Political Economy and Latin Amerika : Theory and Policy. Westview Press. USA.

Lutz, C.H.M. and Tilburg, A (1992). "Methodology to Evaluate The Performance of Markets in The Food Marketing Channel: With an Application to Periodic Markets in Benin". Paper Presented at Workshop on Methods for Agricultural Marketing Research, March 1993, CIP/IARI, New Delhi, India.

Manos et al, (2007), Fertilizer Price Policy, The Environment and Farms Behavior, Journal of Policy Modeling, 29 87-97

Mark, S. (1991). Rural Income and Emplnyment in Indonesia: A Case Study of the Cimanuk River Basin in Java, Unpublished Masters (Horn) thesis, University of Wallongong, Wollongong NSW.

Mc.Corriston, Steve and Ian M. Sheldon, (1991), Government Intervention in Imperfectly Competitive Agricultural Input Markets, American Journal of Agricultural Economics, Vol. 73, No. 3. (Aug., 1991), pp. 621-632.

Mergos ,GJ. and Ch. E. Stoforos, (1997). Fertilizer Demand in Greece, Agricultural Economics, $16227-235$

Moelar Daniel. (2002) Pengantar Ekonomi Pertanian, Bumi Askara, Jakarta

Nixon, Franklin G.M \& James B.W., (1999). Maintaining the Status Quo : Federal Government Budget Deficits and Defensive Rent-Seeking. Jurnal of Economic Studies. Vol 26 no.1.pp 514. MCB. University Press.

North, D.C. and J.J. Wallis (1994). "Integrating Institutional Change and Technical Change in Economic History. A Transaction Cost Approach". Journal of Institutional and Theoretical Economics, 145/1 - pp 609 - 624.

O'Bnen,D. (1989). The Fertiliser Subsidy and Fertiliser Use in Indonesia,Department of Economics, University of Wollongong, Wollongong NSW (mimeo).

Omamo, Steven W and, Lawrence O. Mose, (2001), Fertilizer Trade under Market Liberalization: Preliminary Evidence from Kenya, Food Policy 26 (2001) 1-10

Pitt, Mark M., (1983)..Farm-Level Fertilizer Demand in Java: A Meta-Production Function Approach, American Journal of Agricultural Economics, Vol. 65, No. 3. (Aug., 1983), pp. 502-508.

Rachbini, (2002). Ekonomi Politik, Paradigma dan teori Pilihan Publik. Ghalia Indonesia. Jakarta. 
Ravilion, M, (1986), Testing Market Integration, American Journal of Agricultural Economics, Vol. 68, pp: 102-109

Roche, Frederick C.,(1994), The Technical And Price Efficiency Of Fertiliser Use In Irrigated Rice Production, The BIES. Vol 30 No 1, April 1994. pp. 59-83

Sawit, M. Husein and Dennis OBrien , (1995), Farm Household Responses To Government Policies: Evidence From West Java, The BIES Vol 31 No 2, August 1995, pp. 41-59

Scherer, F.M. and Ross, D (1990). Industrial Market Structure and Economic Performance.Third Edition, Houghton Mifflin Company, Boston.

Shaffer, James D. (1973). On the Concept of Subsektor Studies, American Journal of Agricultural Economics. Vol. 55: 333-335.

Shaffer, James D. (1980), Food System Organization and Performance: Toward a Conceptual Framework, American Journal of Agricultural Economics. Vol. 62, No. 2.

Singarimbun, Masri dan Sofian Effendi. (1995), Metode Penelitian Survei. LP3ES. Jakarta.

Situmorang, J, B. Rachman, M. Iqbal, A. Agustian, Sunarsih, \& V.T. Manurung.(1995). Antisipasi dan Respon petani terhdapa Kebijakasanaan penyesuaian Harga Pupuk dan Gabah. Proyek Pembinaan Kelembagaan Penelitian Pertanian Nasional. Badan Penelitian dan Pengembangan Pertanian,Jakarta.

Soekartawi, (1989). Prinsip Dasar Ekonomi Pertanian. Teori dan Aplikasi. PT. Grafindo Persada. Jakarta.

Soesilowati E. (2002). Analisis Distribusi Pupuk PT. Pupuk Sriwijaya di Jawa Timur. (Kasus di Kabupaten Bangkalan, Malang dan Banyuwangi). Tesis. UPN "Veteran" Jawa Timur. Surabaya.

Steffen, P., (1995), The Role And Limits of The Grain Market in Assuring Household Food Security in Northeastern Malai: Implication for Public Policy, Ph.D Dissertation, Department of Agricultural.

Stern, L.W. and Ansary, A.I.E. (1988). Marketing Channels, 3th Edition. Prentice-Hall International Editions, London.

Sutter Daniel, (1999). Politicians Motives in the Rent SeekingSociety Managerial Finance. Vol.25 Number $3 / 4$.

Syahyuti, 2005. Kebijakan Pengembangan Gabungan Kelompok Tani (Gapoktan) sebagai Lembaga Ekonomi di Pedesaan. Pusat Analisis Sosial Ekonomi dan Kebijakan Pertanian. Bogor.

Tabor, S. (1988), 'Options for Improving the Economic Efficiency of Fertiliser Use', Consultancy Report, Agricultural Sektor Loan Project, World Bank,ASAG, Washmgton DC.

Tomek, W.K, and K.L. Robinson,(1990), Agricultural Product Price, 3th Edition, Cornell University Press

Thomas F. Funk; W. David Downey, (1983) Fertilizer Purchasing Behavior of Indiana Farmers, North Central Journal of Agricultural Economics, Vol. 5, No. 2. (Jul., 1983), pp. 123-137. 
Tilburg, A. van. (1988). Performance Measurement in Respect of Periodic Markets and Marketing Agents Operating at these Markets in Southwest Benin, West-Africa. Proceedings of the European Marketing Academy Conference, Bradford (UK), p. 625-646.

Tintner, Gerhard and Malvika Patel, (1966), Evaluation of Indian Fertilizer Projects: An Application of Consumer's and Producer's Surplus, Journal of Farm Economics, Vol. 48, No. 3, Part 1. (Aug., pp. 704-710.)

Valeriana, A. Rozany N., (2004). Kebijakan Distribusi, Tingkat Harga dan Penggunaan Pupuk di Tingkat Petani. Forum Penelitian Agro Ekonomi Vol. 22 No. 1. Pusat Penelitian dan Pengembangan Sosial Ekonomi Pertanian, Badan Penelitian dan Pengembangan Pertanian. Bogor.

Wanzala, Maria N, (2003), An Economic Analysis of The Performance of Fertilizer Subsektor in The Maize Belt of Western Kenya, Dissertation submitted to Department of Agriculture Economic at Michagan State University.

Wasrob N., (1996). Tataniaga Pertanian. Universitas Terbuka Jakarta. Jakarta.

Williamson, O.E. (1995). The Institutions and Governance of Economic Development and Reform. Proceedings of the World Bank Annual Conference on Development Economics 1994. The World Bank

Williamson, O. (2000). "The New Institutional Economics: Taking Stock, Looking Ahead". Journal of Economic Literature, p.595-613.

Wittenberg, Thomas, (1989). The Soybean Subsektor in Equador : An Analysis of Structure and Government Policy, Thesis, Department of Agricultural Economics at Michagan State University, 1989

Yusmichad Yusdja, Prajogo U. Hadi, Nizwar Syafa'at, Handewi P. Saliem, Saptana, Ketut Karisaya, Sudi Mardianto, Dan M. Maulana, (2006). Kajian Sistem Distribusi Pupuk Dan Usulan Penyempurnaannya : Kasus Di Tiga Propinsi Di Jawa. Pusat Penelitian dan Pengembangan Sosial Ekonomi Pertanian. Bogor

Yustika, A.E. (2005). Transaction Cost Economics of Sugar Industri in Indonesia. Dissertation for Institute of Rural Development, Univeristy of Gottingen. . (2006). Ekonomi Kelembagaan. Definisi, Teori dan Strategi. Bayu Media Publishing. Malang

Zabidi, Yasrin, (2002), Supply Chain Managemen : Teknik Terbaru Mengelola Aliran Material /Produk dan Informasi Dalam Memenangkan Persaingan, Usahawan No 02, Tahun XXX Februari, 2002. 